\title{
Cattle ticks and associated tick-borne pathogens in Burkina Faso and Benin: Apparent northern spread of Rhipicephalus microplus in Benin and first evidence of Theileria velifera and Theileria annulata
}

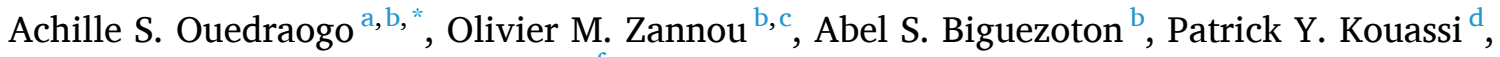 \\ Adrien Belem ${ }^{\mathrm{e}}$, Souaibou Farougou ${ }^{\mathrm{f}}$, Marinda Oosthuizen ${ }^{\mathrm{g}}$, Claude Saegerman ${ }^{\mathrm{c}}$, \\ Laetitia Lempereur ${ }^{\mathrm{h}}$ \\ ${ }^{\text {a }}$ Center for Fundamental and Applied Research for Animal and Health (FARAH), Faculty of Veterinary Medicine, ULiège, 4000 Liège, Belgium \\ ${ }^{\mathrm{b}}$ Vector-borne Diseases and Biodiversity Unit (UMaVeB), International Research and Development Centre on Livestock in Sub-humid Areas (CIRDES), 454 Bobo- \\ Dioulasso 01, Burkina Faso \\ ${ }^{\mathrm{c}}$ Research Unit in Epidemiology and Risk Analysis applied to veterinary sciences (UREAR-ULg), Fundamental and Applied Research for Animal and Health (FARAH) \\ Center, Department of Infectious and Parasitic Diseases, Faculty of Veterinary Medicine, ULiège, 4000 Liège, Belgium \\ ${ }^{\mathrm{d}}$ UFR Biosciences, Université Félix Houphouët Boigny, BP V34, Abidjan 01, Côte d'Ivoire \\ e Institut du Développement Rural (IDR), Université Nazi BONI, 01 BP 1091, Bobo-Dioulasso 01, Burkina Faso \\ ${ }^{\mathrm{f}}$ Unité de Recherche sur les Maladies Transmissibles, Université d'Abomey-Calavi, BP 01 BP 2009 Cotonou, République du Bénin \\ ${ }^{\mathrm{g}}$ Department of veterinary Tropical Diseases, Faculty Veterinary Science, University of Pretoria, 0110 Onderspoort, South Africa \\ ${ }^{\mathrm{h}}$ Federal Public Service Public Health, food safety \& environment, President services, Research coordination, Place victor Horta 40,1060 Brussels, Belgium
}

\section{A R T I C L E I N F O}

\section{Keywords:}

Ticks

Tick-borne pathogens

Cattle

Burkina FFaso

Benin

Rhipicephalus microplus

\begin{abstract}
A B S T R A $\mathrm{T}$
Babesiosis, theileriosis, anaplasmosis, and heartwater are tick-borne diseases that threaten livestock production in sub-Saharan Africa including Burkina Faso and Benin. For over a decade, these two bordering countries have been facing an invasion of the livestock by the tick Rhipicephalus microplus, a major vector for babesiosis, accidentally introduced in Benin in 2004. The molecular identification of tick-borne pathogens in this border area is of particular interest due to animals seasonal migration between the two countries. In this survey, epidemiological features of ticks and tick-borne pathogens in cattle were investigated to compare the eastern Burkina Faso, corresponding to a seasonal migration departure zone, and the northern Benin, which represents a seasonal migration arrival zone. Ticks and peripheral blood were collected from a total of 946 cattle in the two areas. Ticks were morphologically identified and the DNA samples from bovine blood and ticks were analysed by Reverse Line Blot (RLB) hybridization process. A total of 2856 ticks were collected on 490 cattle in Burkina Faso, eight tick species were identified, while 3583 ticks were collected on 456 cattle in North Benin with nine tick species identified. The invasive tick, $R$. microplus was not found in eastern Burkina Faso, but its spread farthest north in Benin is reported. Six tick-borne pathogen species were found in cattle blood both in eastern Burkina Faso and in northern Benin. Ranked in decreasing order of overall prevalences, they are: Theileria mutans (91.1\%), Theileria velifera (77.8\%), Babesia bigemina (10.9\%), Anaplasma marginale (4.2\%), Babesia bovis (3.3\%), and Theileria annulata (1.8\%). To the best of our knowledge, this survey represents the first report of T. velifera and T. annulata in the region. Overall, the TBP prevalences were significantly higher in northern Benin than in eastern Burkina Faso, indicating a higher parasitological risk in this area.
\end{abstract}

\section{Introduction}

Livestock production represents an important economic activity in most West African countries and is a source of income for about $70 \%$ of the population (Nugteren and Le Côme, 2016). Vectors and vector-borne diseases cause high economic losses to the livestock industry, which

\footnotetext{
* Corresponding author.

E-mail addresses: achillouedraogo@gmail.com (A.S. Ouedraogo), marinda.oosthuizen@up.ac.za (M. Oosthuizen), claude.saegerman@uliege.be (C. Saegerman), Laetitia.lempereur@health.fgov.be (L. Lempereur).
} 
hamper the development of this sector particularly in West Africa. Among them, tick-borne diseases cause economic losses to farmers in terms of cattle mortality, loss of body weight and milk production, and costs of their control through chemotherapy (Homewood et al., 2006; Kivaria, 2006). The recorded tick species associated with livestock in West Africa belong mainly to the genera Amblyomma, Hyalomma and Rhipicephalus (including the subgenus Boophilus) (Barker and Murrell, 2004). These vectors can transmit various pathogens (virus, parasites, bacteria) causing important diseases such as babesiosis, theileriosis, anaplasmosis and heartwater (Jongejan and Uilenberg, 2004). Babesiosis, also named "red water fever" remains one of the most common parasitological diseases of livestock worldwide with Babesia bovis being the most pathogenic species in tropical regions. Babesia bovis is mainly acquired and transmitted by $R$. microplus and is transovarially transmitted by this vector species to its larval offspring. In West Africa, recent publications indicate an extension of the distribution of $R$. microplus (Madder et al., 2012; Adakal et al., 2013a; Biguezoton et al., 2016a), which was accidentally introduced in Benin (BN) in 2004 (Madder et al., 2012) and in South West Burkina Faso (BF) in 2011 (Adakal et al., 2013a). The first indication of the introduction of this species was the failure of acaricide treatment as a result of the known high degree of resistance which characterizes this species (George et al., 2004; Adakal et al., 2013b). BN and BF are two countries sharing a border of $285 \mathrm{kms}$ through which seasonal migrations of cattle occur in order to find pasture and watering places during the dry season. Such migrations favor the contact between herds mainly at grazing and watering places, raising the potential spread of transboundary diseases (Zannou et al., 2020). This transversal survey aims to assess the current situation of tick species and the associated pathogens in specific geographical locations corresponding to the departure (eastern BF) and arrival zones (northern $\mathrm{BN}$ ) of the seasonal migration between the two countries. This baseline survey will help further estimations of the potential spread of vectors and transboundary diseases.

\section{Materials and methods}

\subsection{Sampling}

Sampling was carried out from December 2016 to March 2017 (dry season) in eastern $\mathrm{BF}$ and northern BN. Three bordering provinces, namely Gourma $\left(12^{\circ} 9^{\prime} 44.809^{\prime \prime} \mathrm{N} 0^{\circ} 40^{\prime} 38.298^{\prime \prime} \mathrm{E}\right)$, Kompienga $\left(11^{\circ} 31^{\prime}\right.$ $\left.25.81^{\prime \prime} \mathrm{N} 0^{\circ} 45^{\prime} 11.812^{\prime \prime} \mathrm{E}\right)$ and Tapoa $\left(12^{\circ} 14^{\prime} 58.945^{\prime \prime} \mathrm{N} 1^{\circ} 40^{\prime} 33.848^{\prime \prime} \mathrm{E}\right)$, were considered in eastern BF. In northern Benin, four bordering departments, namely Alibori $\left(10^{\circ} 58^{\prime} 5.192^{\prime \prime} \mathrm{N} 2^{\circ} 46^{\prime} 40.732^{\prime \prime} \mathrm{E}\right)$, Atacora $\left(10^{\circ} 47^{\prime} 43.775^{\prime \prime} \mathrm{N} 1^{\circ} 40^{\prime} 33.848^{\prime \prime} \mathrm{E}\right)$, Borgou $\left(9^{\circ} 32^{\prime} 2.71^{\prime \prime} \mathrm{N} 2^{\circ} 46^{\prime} 40.732^{\prime \prime} \mathrm{E}\right)$ and Donga $\left(9^{\circ} 43^{\prime} 9.073^{\prime \prime} \mathrm{N} 1^{\circ} 40^{\prime} 33.848^{\prime \prime} \mathrm{E}\right)$ were chosen (Fig. 1). Cattle herds were selected on a voluntary basis according to criteria such as a minimal cattle herd size of 50 heads and minimal distance of $2 \mathrm{~km}$ between herds. Herds were chosen to cover the most homogenously each province and department of the studied area. The number of herds per province or department involved in the survey was determined based on the size of livestock population in each sampling location and on previous estimated prevalences of tick-borne diseases (Farougou et al., 2007a). Within each herd visited, 10 or 11 cattle were randomly sampled and the age (over and under 12 months) as well as the sex of animals were documented. The exact position of each site was recorded using a global positioning system (GPS) data recorder (Garmin eTrex ${ }^{\circledR}$ 20; Garmin, Hampshire, UK). Each location was transferred into QGIS v.2.18 software and plotted on maps. A total of 946 cattle were sampled in $\mathrm{BF}$ and BN. Based on the CIRDES ethics committee for animal experimentation approval and with the owner consent, cattle were kept in lateral decubitus in order to sample ticks and blood. All ticks found on visible parts of the cattle were systematically removed using pliers during 15 min (Biguezoton et al., 2016a) and conserved in collection tubes with $70 \%$ ethanol. Approximately $5 \mathrm{ml}$ of peripheral blood were collected per animal from the coccygian vein in $9 \mathrm{ml}$ ethylene diamine tetra acetic acid (EDTA) treated vacutainer tubes. Blood was thereafter kept (as spots) on Whatman FTA Cards, air-dried and then packaged in

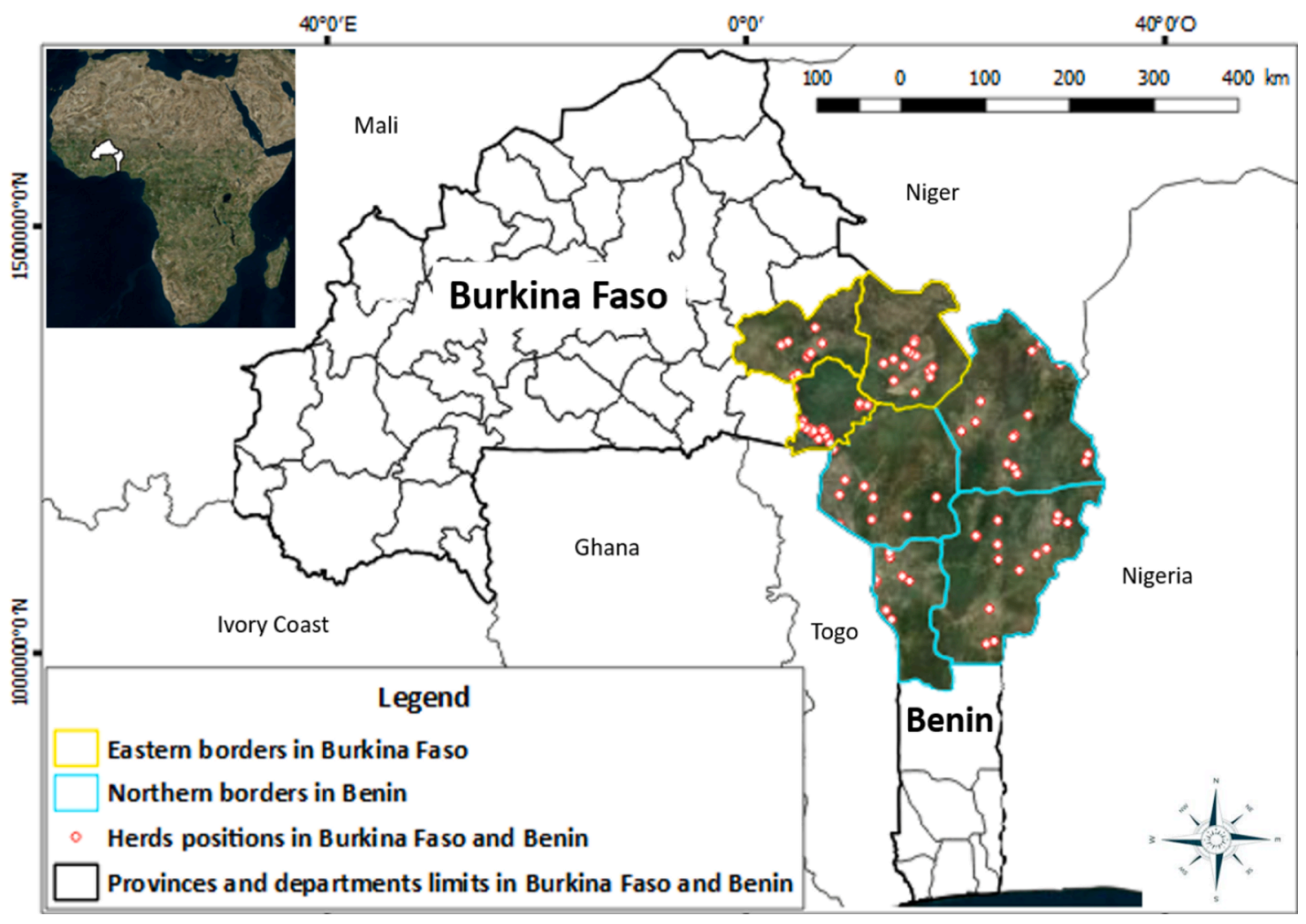

Fig 1. Map showing the 46 sampling sites (herds) in Burkina Faso and 44 in northern Benin. 
safelock sealed bags with silicagel for further analysis.

\subsection{Tick and tick-borne pathogen identification}

Ticks were morphologically identified up to species level, under standard stereomicroscope using Walker et al. (2003) identification key and Horak et al. (2003). Specimens of $R$. microplus were submitted to molecular confirmation following a previously described protocol, targeting the cytochrome oxidase subunit I gene (Silatsa et al., 2019). Tick-borne pathogens (TBP) screening required DNA extraction of ticks and cattle blood followed by a generic PCR and then Reverse Line Blot (RLB) hybridization assay. DNA extraction process was performed on six pieces of five mm diameter of dried blood Whatman FTA cards and on ticks. Among the collected ticks, six species of veterinary interest were selected for pathogen detection. Ticks were pooled (1-5 specimens) per species, cattle, sex and stage. The whole tick was cut into small pieces using scalpel blades, and crushed. DNA extraction was performed using DNeasy Blood \& Tissue Kit (Qiagen; Hilden, Germany) according to the manufacturer's instructions. The quality and concentration of the DNA were assessed using NanoDrop 2000 (Thermo Fisher Scientific, USA). Whole DNA extracts were then stored at $-20^{\circ} \mathrm{C}$ for further analysis.

PCR master mixes were prepared for amplification of DNA fragments of species belonging to genera Theileria/Babesia (Nijhof et al., 2003) and Ehrlichia/Anaplasma (Bekker et al., 2002) using Taq PCR Master Mix Kit (Qiagen, Hilden, Germany). Primers pairs were obtained from Eurogentec (Liège, Belgium), sequences are mentioned in Table 1. Reactions were performed in a $25 \mu \mathrm{l}$ volume with $12.5 \mu \mathrm{l}$ of the PCR buffer master mix, $8 \mathrm{pmol} / \mu \mathrm{l}$ of each primer and $20-50 \mathrm{ng}$ of template DNA. A thermal cycling program was used as previously described (Nijhof et al., 2003).

The RLB hybridization assay (Gubbels et al., 1999; Bekker et al., 2002; Nijhof et al., 2003, 2005) was performed using oligonucleotide probes containing an $\mathrm{N}$-terminal $\mathrm{N}$-(trifluoracetamidohexylcyanoethyl, $N, N$-diisopropyl phosphoramidite)-C6 listed in Table 2. Positive controls for each pathogen were applied to the tests, and molecular grade water was used as negative control. PCR-products of selected TBP and $R$. microplus were subsequently sequenced using Sanger method (GIGA, ULiège, Belgium) after purification (QIAquick PCR Purification Kit, Qiagen; Hilden, Germany) to confirm RLB results. Raw data were analyzed using the freely available BioEdit software (http://www.mbio. ncsu.edu/BioEdit/bioedit.htmldoads). DNA sequences were then compared for similarities with available sequences in GenBank, using the BLASTn program (http://www.ncbi.nlm.nih.gov/BLAST/). Thereafter, sequences were aligned with Clustal $\mathrm{w}$ method and maximum likelihood phylogenetic trees were generated in Mega_X_10.1.7 (https://www.megasoftware.net/). The percentage of bootstraps were calculated applying 500 replicates.

\subsection{Statistical analysis}

Non parametric tests, Fisher exact and Wilcoxon-Mann-Whitney
Table 2

Probe sequences used in reverse line blot hybridization process.

\begin{tabular}{|c|c|c|}
\hline $\begin{array}{l}\text { Genus and species-specific } \\
\text { oligonucleotide probes }\end{array}$ & $\begin{array}{l}\text { Probe Sequences } \\
\text { (from } 5^{\prime}-3^{\prime} \text { ) }\end{array}$ & Reference \\
\hline $\begin{array}{l}\text { Theileria/Babesia gene- } \\
\text { specific }\end{array}$ & $\begin{array}{l}\text { TAA TGG TTA ATA } \\
\text { GGA RCR GTT G }\end{array}$ & Gubbels et al., 1999 \\
\hline $\begin{array}{l}\text { Ehrlichia/Anaplasma gene- } \\
\text { specific }\end{array}$ & $\begin{array}{l}\text { GGG GGA AAG ATT } \\
\text { TAT CGC TA }\end{array}$ & Bekker et al., 2002 \\
\hline Anaplasma marginale & $\begin{array}{l}\text { GAC CGT ATA CGC } \\
\text { AGC TTG }\end{array}$ & Bekker et al., 2002 \\
\hline Anaplasma bovis & $\begin{array}{l}\text { GTA GCT TGC TAT } \\
\text { GRG AAC A }\end{array}$ & Bekker et al., 2002 \\
\hline Anaplasma phagocytophilum & $\begin{array}{l}\text { TTG CTA TAA AGA } \\
\text { ATA ATT AGT GG }\end{array}$ & Bekker et al., 2002 \\
\hline Ehrlichia ruminantium & $\begin{array}{l}\text { AGT ATC TGT TAG } \\
\text { TGG CAG }\end{array}$ & Bekker et al., 2002 \\
\hline Ehrlichia chaffeensis & $\begin{array}{l}\text { ACC TTT TGG TTA } \\
\text { TAA ATA ATT GTT }\end{array}$ & Schouls et al., 1999 \\
\hline Theileria annulata & $\begin{array}{l}\text { CCT CTG GGG TCT } \\
\text { GTG CA }\end{array}$ & Georges et al., 2001 \\
\hline Theileria mutans & $\begin{array}{l}\text { CTT GCG TCT CCG } \\
\text { AAT GTT }\end{array}$ & Gubbels et al., 1999 \\
\hline Theileria annae & $\begin{array}{l}\text { CCG AAC GTA ATT } \\
\text { TTA TTG ATT G }\end{array}$ & $\begin{array}{l}\text { Yisaschar-Mekuzas } \\
\text { et al., } 2013\end{array}$ \\
\hline Theileria taurotragi & $\begin{array}{l}\text { TCT TGG CAC GTG } \\
\text { GCT TTT }\end{array}$ & Gubbels et al., 1999 \\
\hline Theileria velifera & $\begin{array}{l}\text { CCT ATT CTC CTT } \\
\text { TAC GAG T }\end{array}$ & Gubbels et al., 2000 \\
\hline Babesia occultans & $\begin{array}{l}\text { CCT CTT TTG GCC } \\
\text { CAT CTC G }\end{array}$ & He et al., 2012 \\
\hline Babesia microti & $\begin{array}{l}\text { GRC TTG GCA TCW } \\
\text { TCT GGA }\end{array}$ & Nijhof et al., 2003 \\
\hline Babesia major & $\begin{array}{l}\text { TCC GAC TTT GGT } \\
\text { TGG TGT }\end{array}$ & Georges et al., 2001 \\
\hline Babesia bovis & $\begin{array}{l}\text { CAG GTT TCG CCT } \\
\text { GTA TAA TTG AG }\end{array}$ & Gubbels et al., 1999 \\
\hline Babesia bigemina & $\begin{array}{l}\text { CGT TTT TTC CCT } \\
\text { TTT GTT GG }\end{array}$ & Gubbels et al., 1999 \\
\hline
\end{tabular}

(WMW) tests were performed to compare respectively TBP prevalences and the average tick burden of cattle in eastern $\mathrm{BF}$ to those found in northern BN. Pearson's product-moment test (Crawley, 2007) was computed to test for possible correlations between TBP prevalences within tick and cattle. Only TBP recorded in both cattle blood and ticks were considered. Furthermore, relationships between ticks burden on cattle and TBP identified in cattle blood were examined by computing principal correspondence analysis (PCA). PCA was performed using factoextra version 1.0.6 package (http://www.sthda.com/english/rpkgs/factoextra) in $\mathrm{R}$ software version 3.6.1. Only variables (TBP) with a high correlation (greater than 0.5 in absolute value) with the axis of variability (Dim1) were considered for results analyses. In addition, the possible association of the TBP prevalences in cattle with two explanatory variables (cattle age and sex) was assessed computing the odds ratios (OR), with $95 \%$ confidence intervals (CI) and using a logistic regression model in Stata/SE 14.2. For all analyses, a $P$-value

Table 1

Selected primer pairs for the detection of mitochondrial target regions for the genera Babesia/Theileria, Anaplasma/Ehrlichia and for molecular confirmation of Rhipicephalus microplus identification.

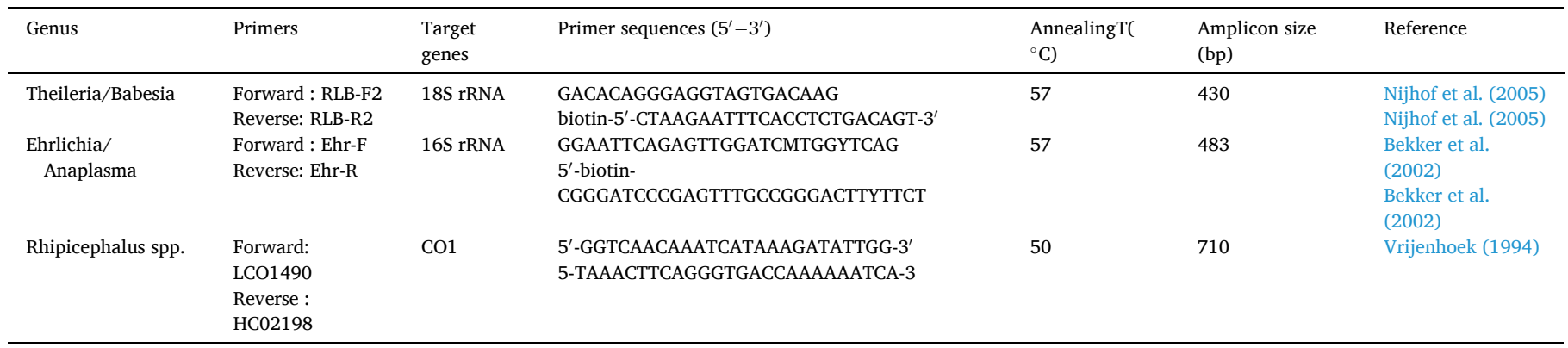

Abbreviation: $T=$ temperature, bp: base pair; CO1: cytochrome c oxidase subunit I gene. 
below 0.05 was considered statistically significant.

\section{Results}

\subsection{Ticks occurrence and abundance on cattle}

A total of 46 flocks were sampled in eastern BF and 44 in northern Benin including 10-11 animals in each herd (Fig. 1). A total of 2856 ticks of eight species were collected on 490 cattle from eastern BF. In northern Benin, 3583 ticks belonging to nine species were sampled on 456 cattle (Table 3). According to WMW test, there was no significant difference between the average tick burden in eastern $\mathrm{BF}(\sim 0.45)$ and in northern BN ( 0.60). Amblyomma variegatum was the most abundant tick species collected from both eastern BF (49.2\%) and northern BN (31\%) (Table 3). The second most abundant species was Hyalomma truncatum in the eastern $\mathrm{BF}(17.3 \%)$ and $R$. microplus in northern $\mathrm{BN}$ (12.6\%). This invasive tick, $R$. microplus was not collected in the eastern $\mathrm{BF}$. In BN, we noticed its apparent spread toward the north in Atacora and Alibori (Fig. 2c) compared to Madder et al. (2012) (Fig. 2a) and De Clercq et al. (2012) (Fig. 2b). Furthermore, within each species, 100\% of the specimens collected were adult, except $A$. variegatum of which $96.2 \%$ and $72.3 \%$ were nymphs in eastern $\mathrm{BF}$ and northern $\mathrm{BN}$ respectively.

\subsection{Tick-borne pathogen prevalences in cattle and in ticks}

Six tick-borne pathogen species were detected in cattle in eastern BF and in northern BN. Theileria mutans was the most prevalent pathogen with $85.3 \%$ of cattle positive in BF and $97.4 \%$ in BN followed by Theileria velifera (Fig. 3). The other species encountered were: Theileria annulata, Babesia bigemina, Babesia bovis and Anaplasma marginale (Fig. 3). The prevalence of T. mutans, T. velifera and B. bigemina, were significantly ( $P$ $<0,05)$ higher in northern BN than in eastern BF. Regarding ticks, out of the 1942 pools tested, pathogens identification revealed seven species, all found in the two areas (Table 4). The TBP species most representative was $T$. mutans both in eastern $\mathrm{BF}$ and in northern $\mathrm{BN}$, with respectively $6.9 \%$ and $2.3 \%$. A. variegatum was the most infected tick species: i.e. all of the seven TBP species evidenced in the ticks were highlighted in this species in both countries (Table 4).

\subsection{Analysis on tick-borne pathogens found both in cattle and tick pools}

Considering whole data (BN and BF), Pearson's product-moment test showed negative correlation (cor $=-0.81 ; P=0.03$ ) between $T$. mutans prevalence in ticks and cattle. Likewise, negative correlation (cor= -0.84; $P=0.02$ ) was observed between $T$. velifera infection rate in ticks and cattle. Such correlations were no more evidenced when data for each country were analysed separately. Meanwhile, the PCA revealed on the circle of correlations graph (Fig. 4a), a positive correlation between T. mutans, T. velifera, B. bovis and B. bigemina prevalence and the first axis of variability (i.e. Dim1). Considering sampling location on the individuals graph (Fig. 4b), it can be observed that these TBP are more encountered in Donga and Borgou than elsewhere. Tapoa and Gourma seem to be the least infected provinces. Regarding ticks, R. geigyi ; $R$. microplus; $R$. annulatus and non identified Rhipicephalus abundances are also significantly $(P<0.05)$ and negatively correlated with the first axis of variability (Fig. 4a). Such results indicate a positive correlation between these tick species and the TBP species cited above (i.e. T. mutans, T. velifera, B. bovis and B. bigemina).

\subsection{Explanatory variables of cattle infection with tick-borne pathogens}

Logistic regression analyses highlighted cattle age as a possible risk variable of animals' infection by T. velifera (OR: 3.4, CI: $2.3-5, P<$ 0.0001 ). Cattle older than 12 months were significantly more infected with $T$. velifera than cattle under 12 months old. In contrary, age appeared as a protective variable for T. mutans infections (OR: $0.3, \mathrm{CI}$ : $0.2-0.5, P<0.0001$ ) (Table 4).

\subsection{Sequences similarities and phylogenetic results}

BLASTn analysis of sequences showed high identity values (i.e. 96-100\%) with published sequences in the GenBank database (Table 6 ) confirming morphological identification of ticks and RLB results of TBP. The maximum likelihood phylogenetic tree in Fig. 5A, dedicated to Theileria/Babesia specimens, showed a clustering of corresponding sequences into four main clades, each containing one or two related sequences generated in this survey. The two sequences of T. mutans (MT250262 \& MT250263) evidenced belongs to the same clade (I) with others strains of T. mutans, but they are distinguishable within a subgroup. This situation is similar to the case of T. annulata (MT259958) (Fig. 1A). The sequences of T. velifera (MT250264) and B. bovis (MT259959) were also gathered within specific clades corresponding to the assigned species in Table 5 (Fig. 5A). Same pattern was observed with A. marginale (MT259778) in Fig. 5B. The Fig. 5C tree was built with reference to (Burger et al., 2014). This enabled the R. microplus sequences generated in this study to be classified in relation to the complex previously defined (Burger et al., 2013; Roy et al., 2018). Two clades of $R$. microplus can be distinguished (Fig. 5C). The clade I containing the sequences generated in northern China and the clade III containing sequences from Africa, south of Asia and of America. The Clades II, IV and

Table 3

Number of ticks and species relative abundances in each province/department of eastern Burkina Faso and northern Benin.

\begin{tabular}{|c|c|c|c|c|c|c|c|c|c|}
\hline \multirow[t]{2}{*}{ Species } & \multicolumn{4}{|c|}{ East Burkina Faso } & \multicolumn{5}{|l|}{ North Benin } \\
\hline & $\begin{array}{l}\text { Gourma }(n= \\
160)\end{array}$ & $\begin{array}{l}\text { Kompienga }(n= \\
165)\end{array}$ & $\begin{array}{l}\text { Tapoa }(n= \\
165)\end{array}$ & $\begin{array}{l}\text { Total No. }(\%) \\
(n=490)\end{array}$ & $\begin{array}{l}\text { Alibori }(n= \\
140)\end{array}$ & $\begin{array}{l}\text { Atacora }(n= \\
88)\end{array}$ & $\begin{array}{l}\text { Borgou ( } n= \\
140)\end{array}$ & $\begin{array}{l}\text { Donga }(n= \\
88)\end{array}$ & $\begin{array}{l}\text { Total No. }(\%) \\
(n=456)\end{array}$ \\
\hline A. variegatum & 502 & 590 & 314 & $1406(49.2)$ & 219 & 159 & 361 & 372 & $1111(31)$ \\
\hline H. truncatum & 123 & 108 & 262 & $493(17.3)$ & 196 & 94 & 100 & 31 & $421(11.7)$ \\
\hline R. geigyi & 62 & 171 & 38 & $271(9.5)$ & 27 & 175 & 106 & 121 & $429(12)$ \\
\hline H. rufipes & 71 & 66 & 93 & $230(8.1)$ & 74 & 20 & 51 & 37 & $182(5.1)$ \\
\hline R. decoloratus & 48 & 54 & 63 & $165(5.8)$ & 85 & 2 & 67 & 4 & $158(4.4)$ \\
\hline R. sanguineus s.l. & 22 & 28 & 30 & $80(2.8)$ & - & - & - & - & - \\
\hline R. muhsamae & 3 & 2 & 3 & $8(0.3)$ & - & - & - & - & - \\
\hline R. senegalensis & 5 & 2 & - & $7(0.2)$ & - & - & - & - & - \\
\hline H. impeltatum & - & - & - & - & 13 & - & - & - & $13(0.4)$ \\
\hline H. impressum & - & - & - & - & 77 & - & - & - & $77(2.1)$ \\
\hline R. microplus & - & - & - & - & 32 & 1 & 233 & 187 & $453(12.6)$ \\
\hline R. annulatus & - & - & - & - & 5 & 0 & 3 & 2 & $10(0.3)$ \\
\hline $\begin{array}{l}\text { Rhipicephalus } \\
\text { spp. }\end{array}$ & 70 & 81 & 45 & 196 (6.9) & 69 & 114 & 306 & 240 & $729(20.3)$ \\
\hline Total & 907 & 1102 & 848 & 2856 & 797 & 565 & 1227 & 994 & 3583 \\
\hline
\end{tabular}

A: Amblyomma; $\mathrm{H}$ : Hyalomma ; $\mathrm{R}$ : Rhipicephalus ; R. sanguineus s.l.: Rhipicephalus sanguineus, sensu lato; $\mathrm{n}$ : number of bovine examined in each province; No: total number of tick species collected in a country; Rhipicephalus. Spp.: unidentified specimens of Rhipicephalus belonging to subgenus Boophilus. 


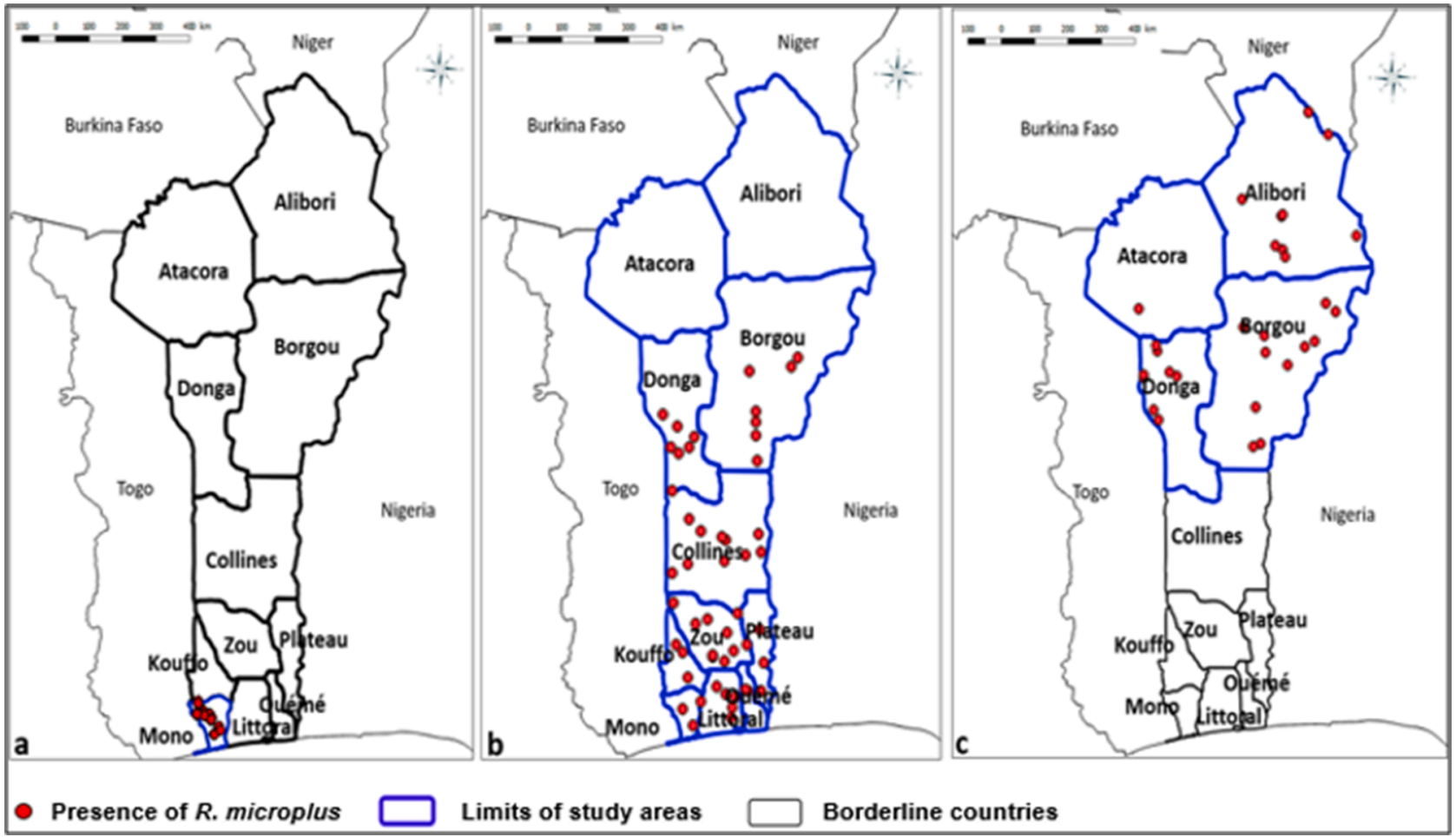

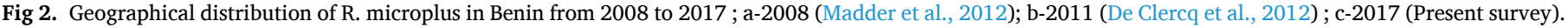

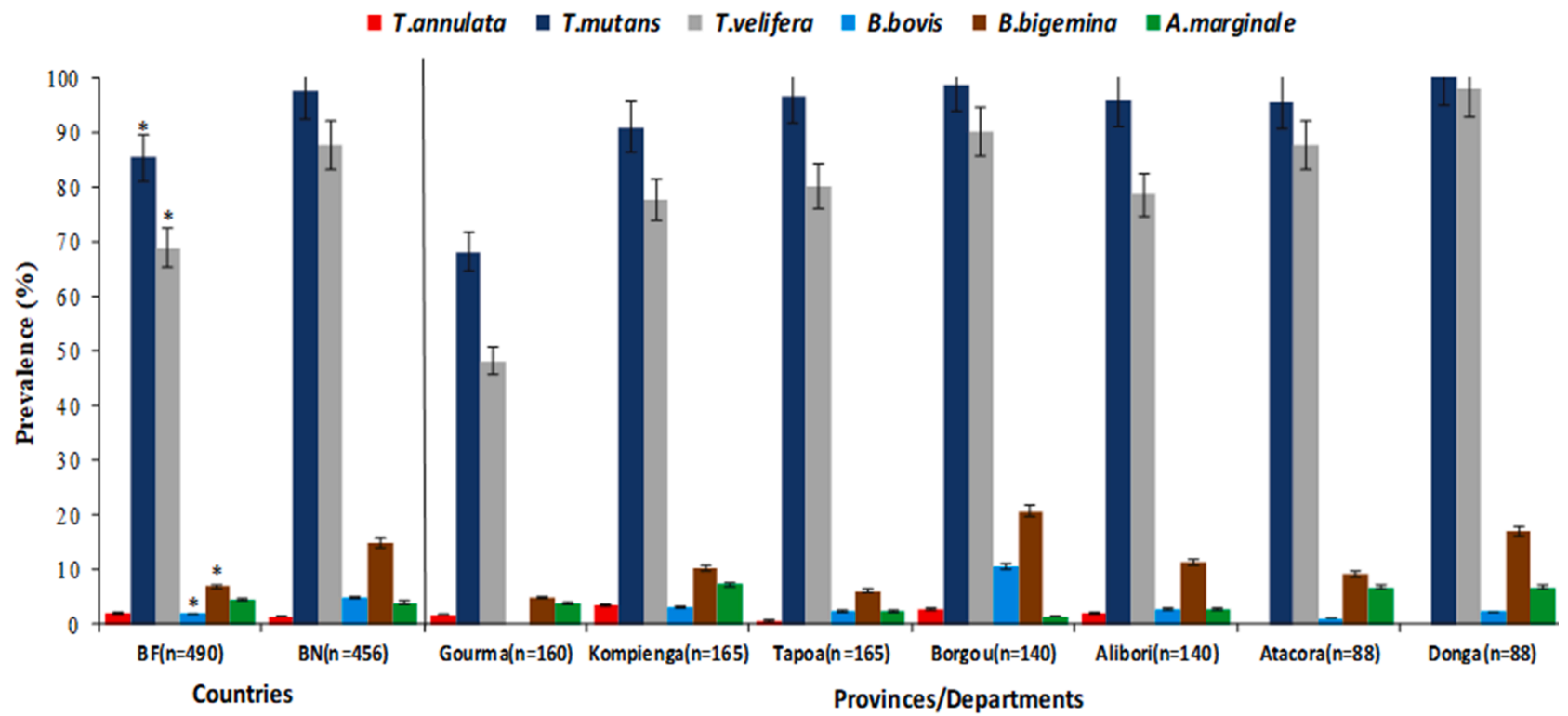

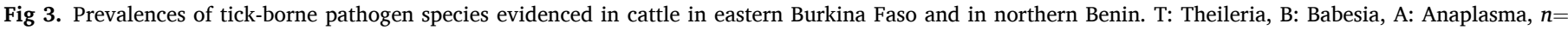
number of cattle examined, bar with stars (*) indicate a P-value $<0.0001$.

$\mathrm{V}$ gather the other species of the subgenus Boophilus (i.e. $R$. annulatus, $R$. geigyi, and $R$. decoloratus).

\section{Discussion}

In Burkina Faso, some areas are very largely unexplored regarding ticks and TBP. This is particularly the case of the eastern part, which received very limited attention. On the opposite, in northern $\mathrm{BN}$, some studies have focused on ticks and TBP but the available data remain limited. In this survey, the abundances of collected ticks in these two areas indicate cattle seem to be more infested by ticks in northern BN than in eastern BF, probably due to the global climatic conditions, as the survey area is globally semi-arid to humid from the eastern BF towards Borgou and Donga departments in northern BN. The tick A. variegatum was the most abundant species, mainly collected in nymph stage in the two areas, as the sampling took place in dry season, corresponding to the high abundance period of $A$. variegatum nymph (Stachurski et al., 1993). Similarly to Biguezoton et al. (2016a), the present survey didn't evidenced the presence of the tick R. microplus in eastern $\mathrm{BF}$ although, it is known to be occurring in western-south BF (Biguezoton et al., 2016a). 
Table 4

Prevalences of tick-borne pathogens detected in ticks pools.

\begin{tabular}{|c|c|c|c|c|c|c|c|c|}
\hline & Tick pools (n) & T.annu No (\%) & T.mu No (\%) & T.ve No (\%) & B.bo No (\%) & B.bi No (\%) & A.ma No (\%) & E.ru No (\%) \\
\hline \multicolumn{9}{|c|}{ Gourma $(n=309)$} \\
\hline A. variegatum & 182 & $1(0.55)$ & $21(11.5)$ & $6(3.3)$ & - & - & - & - \\
\hline H. rufipes & 53 & - & $4(7.5)$ & $3(5.7)$ & $2(3.8)$ & - & - & - \\
\hline R. geigyi & 34 & - & $5(14.7)$ & $1(3.0)$ & - & - & - & - \\
\hline R. decoloratus & 40 & - & $3(7.5)$ & $2(5.0)$ & - & $1(2.5)$ & - & - \\
\hline \multicolumn{9}{|c|}{ Kompienga $(n=351)$} \\
\hline A.variegatum & 185 & - & $17(9.2)$ & $6(3.2)$ & $2(1.1)$ & - & - & $2(1.1)$ \\
\hline H. rufipes & 44 & - & - & - & - & - & - & - \\
\hline R. geigyi & 83 & - & $4(4.8)$ & $2(2.4)$ & - & - & - & - \\
\hline R. decoloratus & 39 & - & $3(7.7)$ & $2(5.1)$ & $1(2.6)$ & $1(2.6)$ & $1(2.6)$ & - \\
\hline \multicolumn{9}{|l|}{ Tapoa $(n=269)$} \\
\hline A.variegatum & 139 & $3(2.2)$ & $6(4.3)$ & $5(3.6)$ & - & - & - & $3(2.3)$ \\
\hline H. rufipes & 60 & 1 (1.7) & $1(1.7)$ & - & - & - & - & - \\
\hline R. geigyi & 28 & - & - & - & $1(3.6)$ & - & - & - \\
\hline R. decoloratus & 42 & $2(4.8)$ & - & - & $1(2.4)$ & - & - & - \\
\hline \multicolumn{9}{|c|}{ Alibori $(n=214)$} \\
\hline A.variegatum & 88 & $4(4.5)$ & $5(5.7)$ & $1(1.1)$ & - & - & - & $4(4.5)$ \\
\hline H. rufipes & 45 & $1(2.2)$ & - & - & - & - & - & - \\
\hline R. geigyi & 15 & - & - & - & - & - & - & - \\
\hline R. decoloratus & 39 & $1(2.6)$ & - & - & $3(7.7)$ & $4(10.2)$ & - & - \\
\hline R. annulatus & 5 & - & - & - & - & - & - & - \\
\hline R. microplus & 22 & - & - & - & $1(4.5)$ & - & - & - \\
\hline \multicolumn{9}{|c|}{ Atacora $(n=140)$} \\
\hline A. variegatum & 59 & - & - & - & - & - & - & - \\
\hline H. rufipes & 11 & - & - & - & - & - & - & - \\
\hline R. geigyi & 66 & $2(3.0)$ & $1(1.5)$ & - & - & - & - & - \\
\hline R. decoloratus & 2 & - & - & - & - & - & - & - \\
\hline R. annulatus & 1 & - & - & - & - & - & _ & - \\
\hline R. microplus & 1 & - & - & - & - & - & - & - \\
\hline \multicolumn{9}{|c|}{ Borgou $(n=372)$} \\
\hline A.variegatum & 145 & $4(2.7)$ & $9(6.2)$ & $2(1.4)$ & - & - & - & $1(0.7)$ \\
\hline H. rufipes & 28 & $2(7.1)$ & - & - & - & - & - & - \\
\hline R. geigyi & 53 & 1 (1.9) & $2(3.8)$ & - & - & $2(3.8)$ & - & - \\
\hline R. decoloratus & 43 & $2(4.6)$ & $2(4.6)$ & - & $1(2.3)$ & $2(4.6)$ & - & - \\
\hline R. annulatus & 8 & - & - & - & - & - & - & - \\
\hline R. microplus & 95 & $4(4.2)$ & $2(2.1)$ & - & - & $1(1.0)$ & - & - \\
\hline \multicolumn{9}{|l|}{ Donga $(n=287)$} \\
\hline A. variegatum & 140 & - & $2(1.4)$ & - & - & - & - & - \\
\hline H. rufipes & 22 & - & - & - & - & - & - & - \\
\hline R. geigyi & 51 & $1(1.9)$ & - & - & - & - & - & - \\
\hline R. decoloratus & 4 & - & - & - & - & - & - & - \\
\hline R. annulatus & 2 & - & - & - & - & - & - & - \\
\hline R. microplus & 68 & - & - & - & - & - & - & - \\
\hline
\end{tabular}

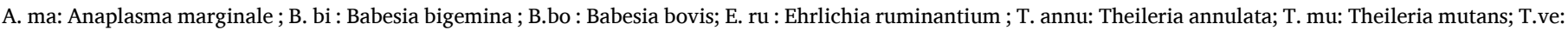
Theileria velifera.

Its abundance in BN could partially explain the apparent difference of tick burden in the two countries, due to its capacity to drive aggregation with others tick species on cattle (Biguezoton et al., 2016a). Furthermore, De Clercq et al. (2012) highlighted the spread of $R$. microplus from the south BN (Mono department) (Madder et al., 2012) to the north in Borgou and Donga. Here, we report its spread farthest north in Atacora and Alibori in complement to the previous distribution pattern published (De Clercq et al., 2013) (Fig. 2b). This could suggest either the opening up of new ecosystems (through direct human impact) favourable to R. microplus proliferation or a possible gradual adaptation of this species to increasingly arid climatic conditions. The phylogenetic analysis of identified specimens indicated the species sampled in northern $\mathrm{BN}$ belong to $R$. microplus sensu stricto group that largely spreads in the world (Burger et al., 2014). Besides, the closeness of our sequences (MT249801 \& MT249802) to that of Brazil (KC503261) (Fig. 5C) reinforce the hypothesis of Brazilian origin of $R$. microplus invasion in Benin (Madder et al., 2012). Furthermore, the high tick infestation of cattle in northern BN seems to result in higher TBP prevalences in cattle in this area compared to those in eastern BF. This concerns especially T. mutans and T. velifera, which showed high prevalences there (Fig. 3). Such high prevalences were reported in other African countries (Simuunza et al., 2011; Lorusso et al., 2016 ; Abanda et al., 2019). That should be attributed to cattle being year-round highly exposed to the vector tick
A. variegatum (Farougou et al., 2007b; Walker et al., 2003; Haghi et al., 2017), an endemic species in the region. Strangely, ticks collected from cattle infected with these two pathogens were not found systematically positive. The negative correlation could be attributed to the low parasitemia in infected cattle blood. It becomes very unlikely to detect Theileria DNA in crushed ticks if the ingested merozoïtes (from cattle) are not enough to anable the tick infection. The greater part of cattle found positive were symptomless as T. mutans is known to belong to Theileria spp. benign group (Mans et al., 2015; Abdela and Bekele, 2016) and T. velifera is known to cause only mild or subclinical infections (Radostits et al., 2006). In addition, cattle could be protected by the effect of certain trypanocidal compounds such as diminazene aceturate, which has an inhibitory effect on Theileria and Babesia species (Baek et al., 2002) and is commonly used in the study area. Among the positive cattle, those older than 12 months were significantly more infected with T. velifera, than those under 12 months old probably because of their contact with the vector ticks for a longer period of their lives. However, to our knowledge, this survey represents the first report of T. velifera in $\mathrm{BF}$ and BN, as well as for T. annulata. They were found both in cattle blood and in their known vector ticks (A. variegatum for T. velifera and Hyalomma sp. for T. annulata). However, we found them in some tick species not known to be their vector (Mans et al., 2015), such as $R$. decoloratus and $R$. geigyi. Obviously, this result does not imply these 


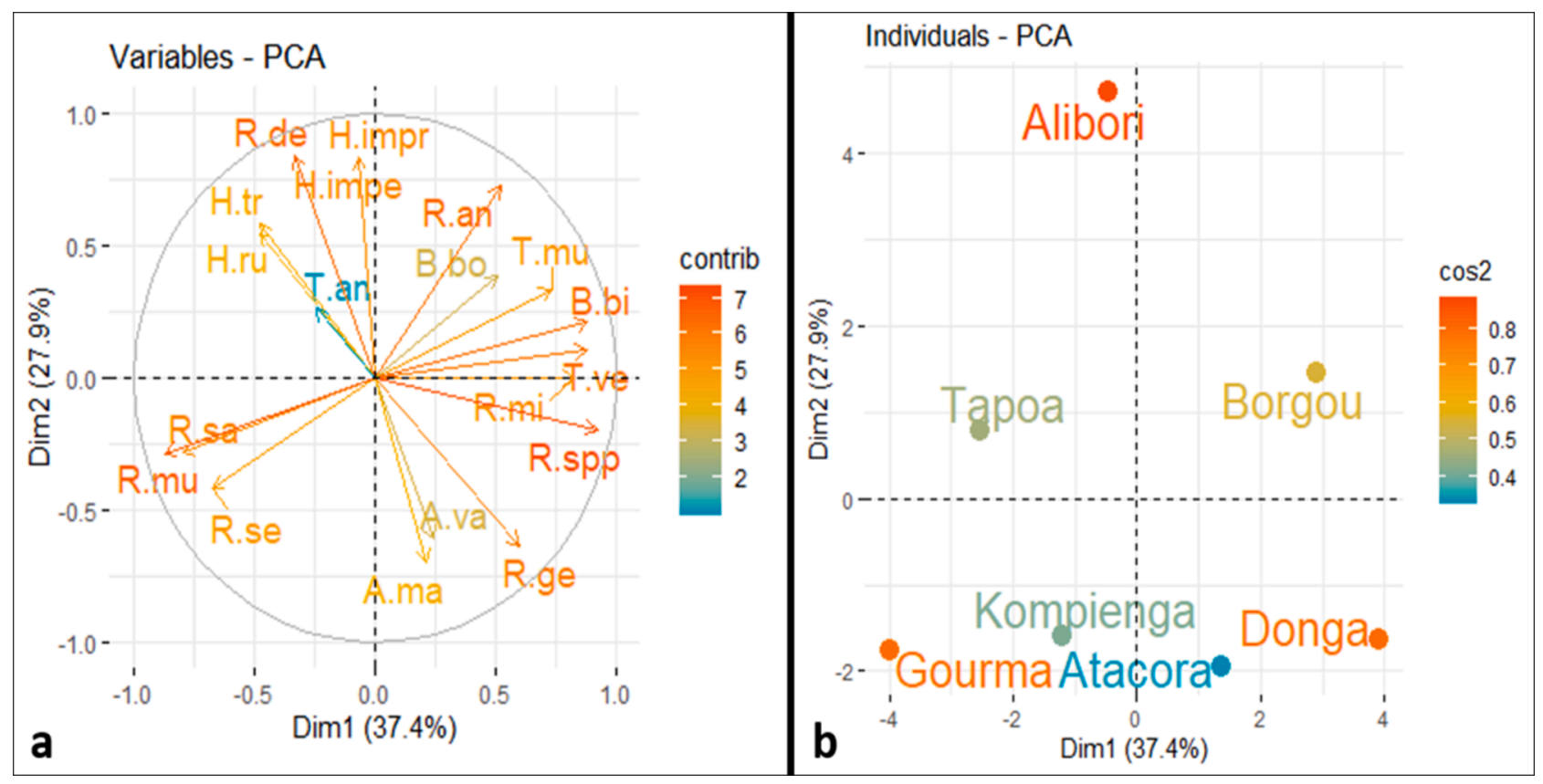

Fig 4. Links between tick-borne pathogens in cattle and ticks collected on cattle according to locations of sampling in eastern Burkina Faso and northern Benin

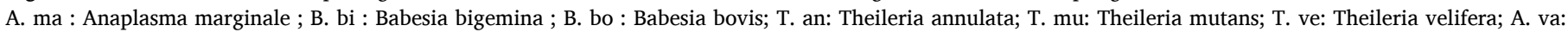

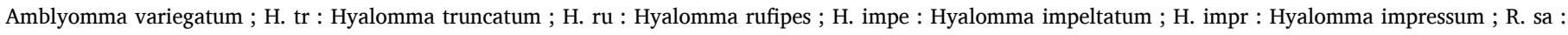

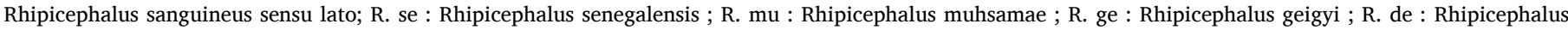

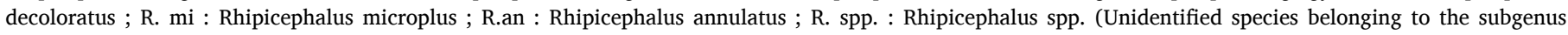
Boophilus), Contrib: contribution.

Table 5

Explanatory variables for cattle infection by tick-borne pathogens.

\begin{tabular}{clll}
\hline \multicolumn{1}{l}{ TBP } & OR/95\% CI/P & Age & Sex \\
\hline \multirow{2}{*}{ Theileria annulata } & OR & 2.1 & 0.8 \\
& $95 \%$ CI & $0.6-7.1$ & $0.25-2.8$ \\
\multirow{4}{*}{ Theileria mutans } & P & 0.2 & 0.8 \\
& OR & 0.3 & 1.5 \\
Theileria velifera & $95 \%$ CI & $0.2-0.5$ & $0.8-2.8$ \\
& P & $<0.0001$ & 0.2 \\
Babesia bovis & OR & 3.4 & 1 \\
& $95 \%$ CI & $2.3-5.0$ & $0.7-1.5$ \\
Babesia bigemina & P & $<0.0001$ & 0.9 \\
& OR & 1.2 & 1 \\
Anaplasma marginale & $95 \%$ CI & $0.5-2.7$ & $0.4-2.4$ \\
& P & 0.7 & 0.9 \\
& OR & 0.7 & 1.5 \\
& $95 \%$ CI & $0.4-1.1$ & $0.9-2.3$ \\
& OR & 0.1 & 0.1 \\
& $95 \%$ CI & 1.1 & 1.5 \\
& P & $0.6-2.3$ & $0.7-2.9$ \\
\hline
\end{tabular}

TBP: Tick-borne pathogens; OR: odds ratio, CI: confidence interval, $P$ : probability.

Pathogens for which the variables are significantly explanatory are indicated in bold.

tick species are competent for T. annulata transmission. Even if we scraped blood from engorged ticks prior to DNA extraction, it is not excluded that they were infected because of a blood meal taken from infected animals. On the African continent, T. annulata was known to be occurring in North Africa, Middle East Africa, in Sudan and in Mauritania (d'Oliveira et al., 1997 ; Gubbels et al., 2000 ; Mohamed and Ebied, 2014). Its detection in the present survey may provide evidence of a change in its previous distribution pattern.

According to Babesia genus TBP detection, in cattle the prevalence of $B$. bigemina and $B$. bovis were significantly higher in northern $\mathrm{BN}$, especially in Borgou and Donga than other departments, probably
Table 6

Representative sequences published in GenBank for tick-borne pathogens and Rhipicephalus microplus.

\begin{tabular}{|c|c|c|c|c|c|}
\hline $\begin{array}{l}\text { GenBank } \\
\text { ID }\end{array}$ & Samples & Species & $\begin{array}{l}\text { Size } \\
\text { (bp) }\end{array}$ & $\%$ ID & Origin \\
\hline MT250262 & Gou07-47 & Theileria mutans & 528 & 96.34 & $\begin{array}{l}\text { Gourma, } \\
\text { BF }\end{array}$ \\
\hline MT250263 & Gou03-04 & Theileria mutans & 414 & 99.76 & $\begin{array}{l}\text { Gourma, } \\
\text { BF }\end{array}$ \\
\hline MT250264 & Gou03-07 & Theileria velifera & 531 & 99.06 & $\begin{array}{l}\text { Gourma, } \\
\text { BF }\end{array}$ \\
\hline MT259958 & Bor02-10 & Theileria annulata & 371 & 100 & $\begin{array}{l}\text { Borgou, } \\
\text { BN }\end{array}$ \\
\hline MT259959 & Don06-07 & Babesia bovis & 351 & 96.87 & $\begin{array}{l}\text { Donga, } \\
\text { BN }\end{array}$ \\
\hline MT259778 & $\begin{array}{l}\text { Gou03- } \\
\text { bov07 }\end{array}$ & $\begin{array}{l}\text { Anaplasma } \\
\text { marginale }\end{array}$ & 490 & 98.52 & $\begin{array}{l}\text { Gourma, } \\
\text { BF }\end{array}$ \\
\hline MT249801 & Be382 & $\begin{array}{l}\text { Rhipicephalus } \\
\text { microplus }\end{array}$ & 674 & 99.85 & $\begin{array}{l}\text { Alibori, } \\
\text { BN }\end{array}$ \\
\hline MT249802 & Be407 & $\begin{array}{l}\text { Rhipicephalus } \\
\text { microplus }\end{array}$ & 643 & 100 & $\begin{array}{l}\text { Alibori, } \\
\mathrm{BN}\end{array}$ \\
\hline
\end{tabular}

because of the occurrence of their principal vector $R$. microplus (Walker et al., 2003 ; Haghi et al., 2017).

Babesiosis clinical signs (Mohamed and Ebied, 2014 ; Demessie and Derso, 2015) were not apparent in sampled cattle, leading to hypothesized a stable endemicity of Babesia species in the region, as previously observed by Adehan et al. (2016). Babesia bovis was evidenced in cattle in eastern $\mathrm{BF}$, however its principal vector $R$. microplus (Dantas-Torres et al., 2012; Grisi et al., 2014), was not found there. This suggests cattle of eastern $\mathrm{BF}$ were infected with $B$. bovis after their exposure to $R$. microplus or other competent species, during their seasonal migration in northern BN through transhumance corridors (Zannou et al., 2020). However, this hypothesis requires more investigations considering cattle transboundary movements. The detection of A. marginale was expected in this survey as this pathogen is known to be endemic worldwide 

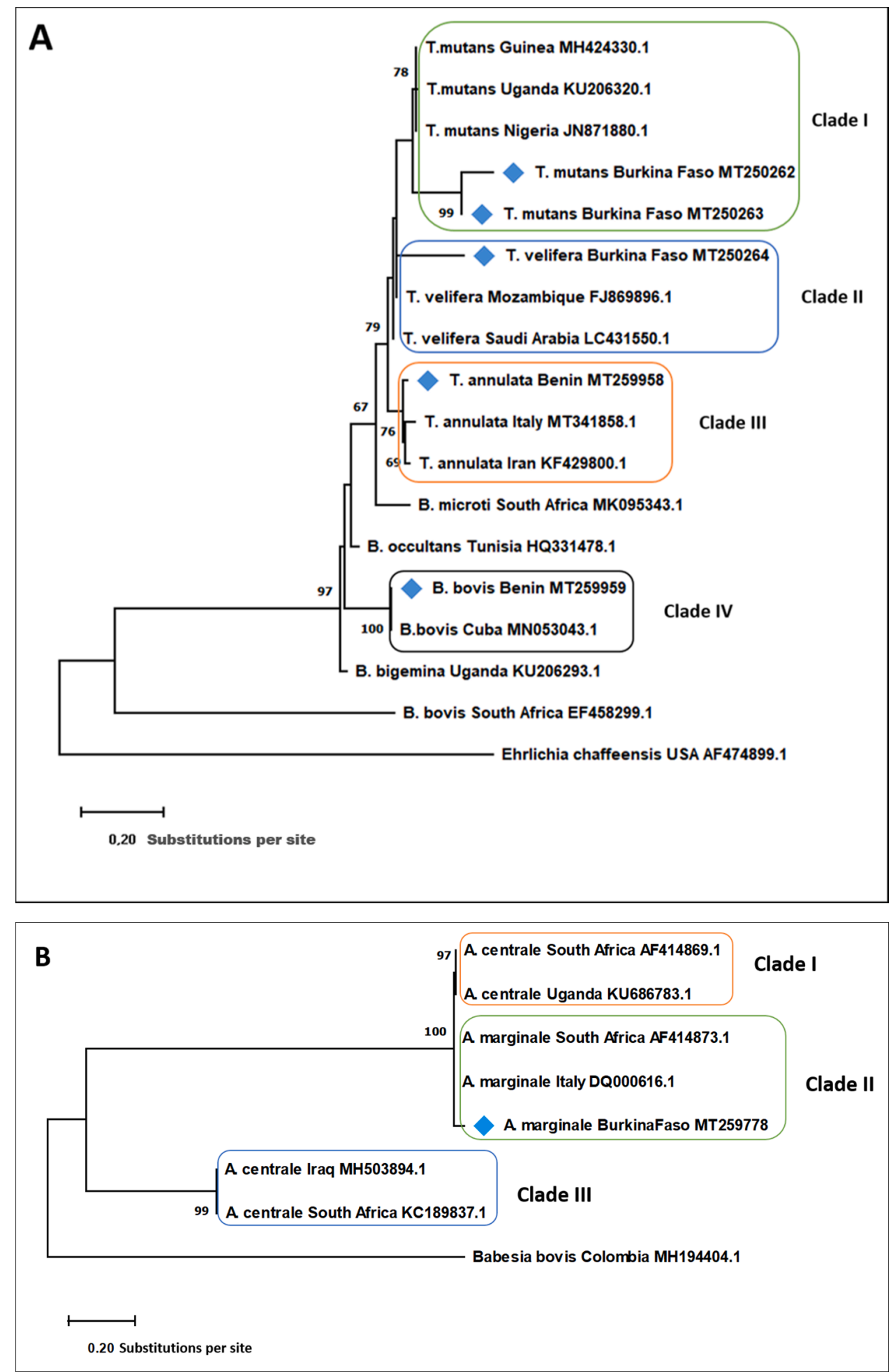

Fig 5. Phylogenetic trees of $18 \mathrm{~S}$ gene sequences of Theileria/Babesia (A), 16S gene sequences of Ehrlichia/Anaplasma (B) and CO1 gene sequences of Rhipicephalus spp. (C) constructed with the Maximum Likelihood method. Evolutionary history was inferred applying Tamura-Nei model. Blue squares refer to sequences generated in the present study.

especially in tropical and subtropical areas (Kocan and de la Fuente, 2003). It has been found only in examined cattle (and not in ticks) without significant difference in prevalence between the eastern BF and northern BN although its vector ticks, A. variegatum and Rhipicephalus spp. (Harrison et al., 2011 ; Sisson et al., 2017), are widespread and has a similar distribution in the two areas. Some pools of $A$. variegatum were found positive to Ehrlichia ruminantium. This result was also expected as the presence of this pathogen is well known in the region (Adakal et al., 2010; Farougou et al., 2012; Biguezoton et al., 2016b; Adjou Moumouni et al., 2018) sometimes with high prevalence.

The main limitation of this survey is due to its transversal nature. Some interesting explanatory variables were identified. To verify if these 


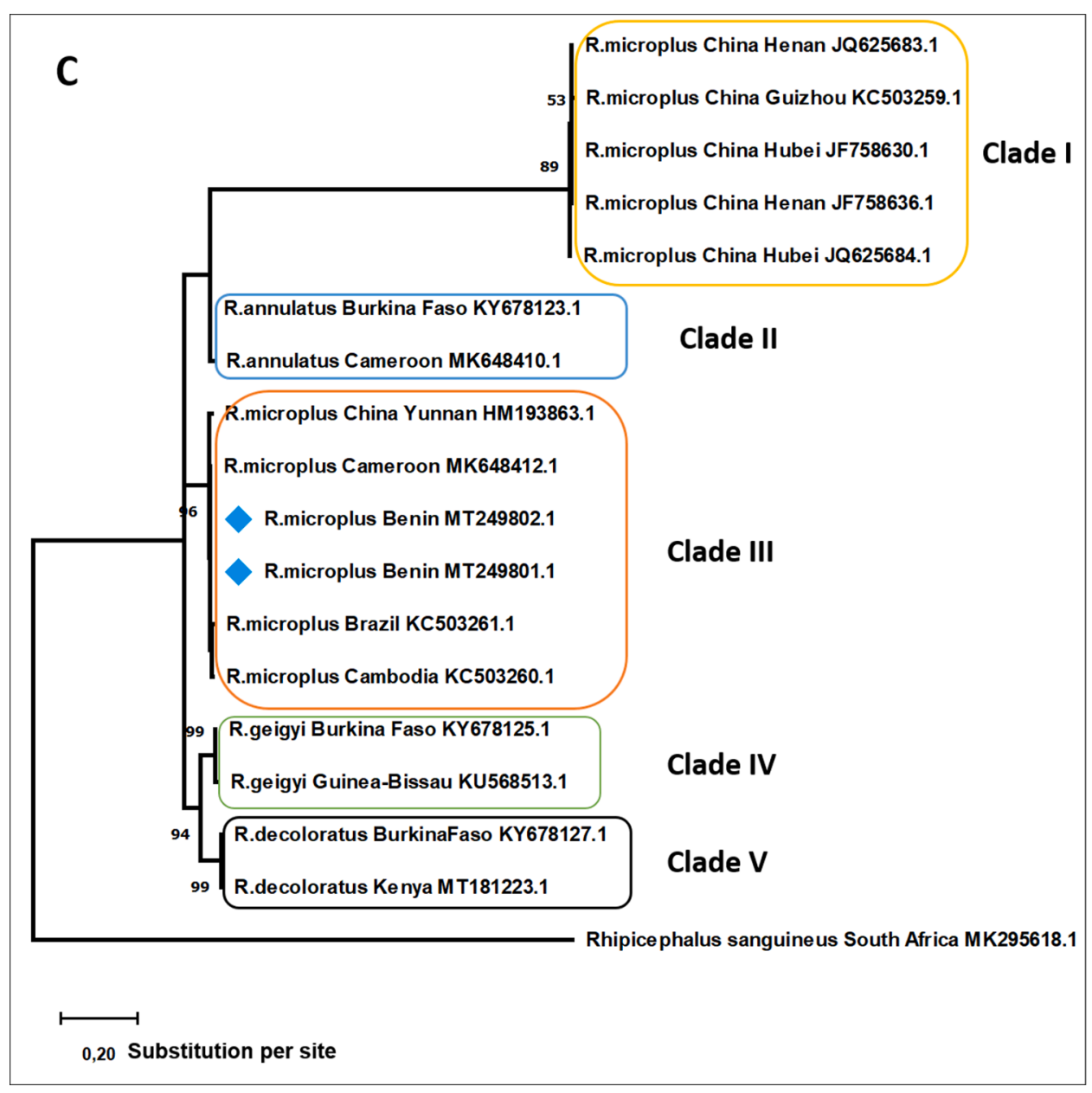

Fig 5. (continued).

variables are true risk or protective factors, future longitudinal studies are required in order to demonstrated the anteriority of these factors on their effects.

\section{Conclusion}

Before the accidental introduction of $R$. microplus in the West African sub-region, the livestock production sector was facing challenges induced by other tick species such as A. variegatum, Hyalomma spp., Rhipicephalus spp. As R. microplus was found to be resistant to most of the acaricidal products used in this area, difficulties associated with ticks control in livestock farming in the area were increased. The spreading of this invasive tick species in West Africa seems to be accompanied by an adaptation to more arid area. A wide area in northern $\mathrm{BN}$ is yet invaded around ten years after the first identification of the tick species in southern BN. Added to this, considering animals annual migration between eastern $\mathrm{BF}$ and northern $\mathrm{BN}$, it is possible that the invasive tick invades eastern $\mathrm{BF}$ if stringent control measures are not applied. Most of TBP highlighted in this survey (T. mutans, B. bigemina, B. bovis, A. marginale and $E$. ruminantium) are known to be present in the study area. However, this survey highlights for the first time the presence of T. velifera and T. annulata in Benin and Burkina Faso. In addition, if T. velifera has yet been evidenced in West Africa (Lorusso et al., 2016), to our knowledge that is the first time T. annulata is identified in this part of the continent. Considering overall pathogen prevalences detected in this study, parasitological risk seems to be higher in the northern BN than in eastern $\mathrm{BF}$, due to cattle infestation with higher abundances and diversified vector tick species.
Declarations of Competing Interest

None.

Acknowledgments

The authors are grateful to Milana Troskie from the University of Pretoria for her technical support. Positive controls were kindly provided by the Department of veterinary Tropical Diseases, Faculty Veterinary Science, University of Pretoria and the Institute of Tropical Medicine of Antwerp. We would like to thank lab technicians at CIRDES for their contribution to the samples processing and farmers in BF and $\mathrm{BN}$ for lending their animals for samples collection. We would like also to acknowledge the breeders' associations that facilitated the enrolment of the farms involved in this survey and the provincial and local authorities of eastern BF and northern BN for their collaboration.

\section{Sample CRediT author statement}

Conceptualization, Methodology, Project administration (LL, AB, PY, CS), Data acquisition \& Field work (AO, OM); Supervision (LL, AB); Writing - original draft (AO); Review \& editing (LL, CS, AB, MO, SF, OM, PY).

Funding

This work was supported by the Academy of Research and Higher Education (ARES-CCD) [RPD Transticks] 


\section{Ethical statements}

The transversal survey was approved by CIRDES ethics committee (CE-CIRDES) for animal experimentation according to this reference number: 001-02/2017/CE-CIRDES.

\section{References}

Abanda, B., Paguem, A., Abdoulmoumini, M., Kingsley, M.T., Renz, A., Eisenbarth, A., 2019. Molecular identification and prevalence of tick-borne pathogens in zebu and taurine cattle in North Cameroon. Parasites Vectors 12, 448. https://doi.org/ 10.1186/s13071-019-3699-x.

Abdela, N., Bekele, T., 2016. Bovine theileriosis and its control: a review. Adv. Biol. Res. 10, 200-212.

Adakal Biguezoton, A., Zoungrana, S., Courtin, F., De Clercq, E.M., Madder, M., 2013a. Alarming spread of the Asian cattle tick Rhipicephalus microplus in West Africa-Another three countries are affected: burkina Faso, Mali and Togo. Exp. Appl. Acarol. 61, 383-386. https://doi.org/10.1007/s10493-013-9706-6.

Adakal, H., Gavotte, L., Stachurski, F., Konkobo, M., Henri, H., Zoungrana, S., Huber, K., Vachiery, N., Martinez, D., Morand, S., Frutos, R., 2010. Clonal origin of emerging populations of Ehrlichia ruminantium in Burkina Faso. Infect. Genet. Evol. 10, 903-912. https://doi.org/10.1016/j.meegid.2010.05.011.

Adakal, Hassane, Stachurski, F., Chevillon, C., 2013b. Tick control practices in Burkina Faso and acaricide resistance survey in Rhipicephalus (Boophilus) geigyi (Acari: ixodidae). Exp. Appl. Acarol. 59, 483-491. https://doi.org/10.1007/s10493-012 9610-5.

Adehan, B.S., Abel, B., Aquilas, D., Marc, N.A., Razacki, A., Hassane, A., Guy, A.M., Soua iuml bou, F., Maxime, M., 2016. Blood survey of Babesia spp. and Theileria spp. in Monos cattle. Benin. Afr. J. Agric. Res. 11, 1266-1272. https://doi.org/10.5897/ AJAR2015.10055.

Adjou Moumouni, P.F., Aplogan, G.L., Katahira, H., Gao, Y., Guo, H., Efstratiou, A., Jirapattharasate, C., Wang, G., Liu, M., Ringo, A.E., Umemiya-Shirafuji, R., Suzuki, H., Xuan, X., 2018. Prevalence, risk factors, and genetic diversity of veterinary important tick-borne pathogens in cattle from Rhipicephalus microplusinvaded and non-invaded areas of Benin. Ticks Tick Borne Dis. 9, 450-464. https:// doi.org/10.1016/j.ttbdis.2017.12.015.

Baek, B.-.K., Lee, Y.-.J., Kim, B.-.S., 2002. Antiparasitic effect of diminazene aceturate on Theileria sergenti types in calves. Taehan Suui Hakhoe Chi Taehan Suui Hakhoe 42, 261-268.

Barker, S.C., Murrell, A., 2004. Systematics and evolution of ticks with a list of valid genus and species names. ParasitologyParasitology 129. https://doi.org/10.1017/ S0031182004005207. S15-S36.

Bekker, C.P.J., de Vos, S., Taoufik, A., Sparagano, O.A.E., Jongejan, F., 2002. Simultaneous detection of Anaplasma and Ehrlichia species in ruminants and detection of Ehrlichia ruminantium in Amblyomma variegatum ticks by reverse line blot hybridization. Vet. Microbiol. 89, 223-238. https://doi.org/10.1016/S03781135(02)00179-7.

Biguezoton, A., Adehan, S., Adakal, H., Zoungrana, S., Farougou, S., Chevillon, C., 2016a. Community structure, seasonal variations and interactions between native and invasive cattle tick species in Benin and Burkina Faso. Parasites Vectors. https:// doi.org/10.1186/s13071-016-1305-z, 9.

Biguezoton, A., Noel, V., Adehan, S., Adakal, H., Dayo, G.-.K., Zoungrana, S., Farougou, S., Chevillon, C., 2016b. Ehrlichia ruminantium infects Rhipicephalus microplus in West Africa. Parasites Vectors. https://doi.org/10.1186/s13071-0161651-x, 9.

Burger, T.D., Shao, R., Labruna, M.B., Barker, S.C., 2014. Molecular phylogeny of soft ticks (Ixodida: argasidae) inferred from mitochondrial genome and nuclear rRNA sequences. Ticks Tick-Borne Dis. 5, 195-207. https://doi.org/10.1016/j ttbdis.2013.10.009.

Crawley, M.J., The, R., 2007. Book. England. John Wiley \& Sons Ltd.

d'Oliveira, C., van der Weide, M., Jacquiet, P., Jongejan, F., 1997. Detection of Theileria annulata by the PCR in ticks (Acari: ixodidae) collected from cattle in Mauritania. Exp. Appl. Acarol. 21, 279-291. https://doi.org/10.1023/A:1018455223462.

Dantas-Torres, F., Chomel, B.B., Otranto, D., 2012. Ticks and tick-borne diseases: a one health perspective. Trends Parasitol. 28, 437-446. https://doi.org/10.1016/j. pt.2012.07.003.

De Clercq, E.M., Estrada-Peña, A., Adehan, S., Madder, M., Vanwambeke, S.O., 2013. An update on distribution models for Rhipicephalus microplus in West Africa.

De Clercq, E.M., Vanwambeke, S.O., Sungirai, M., Adehan, S., Lokossou, R., Madder, M. 2012. Geographic distribution of the invasive cattle tick Rhipicephalus microplus, a country-wide survey in Benin. Exp. Appl. Acarol. 58, 441-452. https://doi.org/ 10.1007/s10493-012-9587-0.

Demessie, Y., Derso, S., 2015. Tick borne hemoparasitic diseases of ruminants: a review. Adv. Biol. Res. 9, 210-224.

Farougou, S., Adakal, H., Biguezoton, A.S., Boko, C., 2012. Prévalence de l'infection d'Amblyomma variegatum par Ehrlichia ruminantium dans les élevages extensifs du Bénin. Rev. Méd. Vét. 163, 261.

Farougou, S., Kpodekon, M., Tassou, A.W.Y., 2007b. Abondance saisonnière des tiques (Acari : ixodidae) parasites des bovins dans la zone soudanienne du Bénin : cas des départements du Borgou et de l'Alibori. Rev. Afric Santé Prod. Anim. 5, 61-67.

Farougou, S., Tassou, A.W., Tchabode, D.M., Podekon, M., Boko, C., Youssao, A.K.I., 2007a. Tiques et hémoparasites du bétail dans le nord-Bénin. Rev. Méd. Vét 158 (8-9), 463-467.
George, J.E., Pound, J.M., Davey, R.B., 2004. Chemical control of ticks on cattle and the resistance of these parasites to acaricides. Parasitology 129. https://doi.org/ 10.1017/S0031182003004682. S353-S366.

Georges, K., Loria, G.R., Riili, S., Greco, A., Caracappa, S., Jongejan, F., Sparagano, O., 2001. Detection of haemoparasites in cattle by reverse line blot hybridisation with a note on the distribution of ticks in Sicily. Vet. Parasitol. 99, 273-286. https://doi. org/10.1016/S0304-4017(01)00488-5.

Grisi, L., Leite, R.C., Martins, J.R, de S., Barros, A.T.M.de, Andreotti, R., Cançado, P.H.D., León, A.A.P.de, Pereira, J.B., Villela, H.S., Grisi, L., Leite, R.C., Martins, J.R.de S., Barros, A.T.M.de, Andreotti, R., Cançado, P.H.D., León, A.A.P.de, Pereira, J.B., Villela, H.S., 2014. Reassessment of the potential economic impact of cattle parasites in Brazil. Rev. Bras. DE Parasitol. Vet. 23, 150-156. https://doi.org/10.1590/S198429612014042.

Gubbels, J.M., Vos, A.P.de, Weide, M.van der, Viseras, J., Schouls, L.M., Vries, E.de, Jongejan, F., 1999. Simultaneous detection of bovine theileria and babesia species by reverse line blot hybridization. J. Clin. Microbiol. 37, 1782-1789.

Gubbels, M.-.J., Katzer, F., Hide, G., Jongejan, F., Shiels, B.R., 2000. Generation of a mosaic pattern of diversity in the major merozoite-piroplasm surface antigen of Theileria annulata. Mol. Biochem. Parasitol. 110, 23-32. https://doi.org/10.1016/ S0166-6851(00)00253-X.

Haghi, M.M., Etemadifar, F., Fakhar, M., Teshnizi, S.H., Soosaraei, M., Shokri, A., Hajihasani, A., Mashhadi, H., 2017. Status of babesiosis among domestic herbivores in Iran: a systematic review and meta-analysis. Parasitol. Res. 116, 1101-1109. https://doi.org/10.1007/s00436-016-5368-8.

Harrison, A., Bown, K.J., Horak, I.G., 2011. Detection of anaplasma bovis in an undescribed tick species collected from the eastern rock sengi elephantulus myurus. J. Parasitol. 97, 1012-1016. https://doi.org/10.1645/GE-2800.1.

He, L., Feng, H.-.H., Zhang, W.-.J., Zhang, Q.-.L., Fang, R., Wang, L.-.X., Tu, P., Zhou, Y.-. Q., Zhao, J.-.L., Oosthuizen, M.C., 2012. Occurrence of Theileria and Babesia species in water buffalo (Bubalus babalis, Linnaeus, 1758) in the Hubei province, South China. Vet. Parasitol. 186, 490-496. https://doi.org/10.1016/j.vetpar.2011.11.021.

Homewood, K., Trench, P., Randall, S., Lynen, G., Bishop, B., 2006. Livestock health and socio-economic impacts of a veterinary intervention in Maasailand: infection-andtreatment vaccine against East Coast fever. Agric. Syst. 89, 248-271. https://doi. org/10.1016/j.agsy.2005.09.004.

Horak, I.G., Camicas, J.-.L., Keirans, J.E., 2003. The Argasidae, Ixodidae and Nuttalliellidae (Acari: ixodida): a world list of valid tick names. In: Jongejan, F., Kaufman, W.R. (Eds.), Ticks and Tick-Borne Pathogens: Proceedings of the 4th International Conference on Ticks and Tick-Borne Pathogens The Banff Centre Banff. Alberta, Canada, pp. 27-54. https://doi.org/10.1007/978-94-017-3526-1_2, 21-26 July 2002. Springer Netherlands, Dordrecht, pp.

Jongejan, F., Uilenberg, G., 2004. The global importance of ticks. Parasitology 129. https://doi.org/10.1017/S0031182004005967. S3-S14.

Kivaria, F.M., 2006. Estimated direct economic costs associated with tick-borne diseases on cattle in Tanzania. Trop Anim. Health Prod. 38, 291-299. https://doi.org/ 10.1007/s11250-006-4181-2.

Kocan, K.M., de la Fuente, J., 2003. Co-feeding studies of ticks infected with Anaplasma marginale. Vet. Parasitol. 112, 295-305. https://doi.org/10.1016/S0304-4017(03) 00018-9.

Lorusso, V., Wijnveld, M., Majekodunmi, A.O., Dongkum, C., Fajinmi, A., Dogo, A.G., Thrusfield, M., Mugenyi, A., Vaumourin, E., Igweh, A.C., Jongejan, F., Welburn, S.C., Picozzi, K., 2016. Tick-borne pathogens of zoonotic and veterinary importance in Nigerian cattle. Parasites Vectors 9, 217. https://doi.org/10.1186/s13071-0161504-7.

Madder, M., Adehan, S., Deken, R.D., Adehan, R., Lokossou, R., 2012. New foci of Rhipicephalus microplus in West Africa. Exp. Appl. Acarol. 56, 385-390. https://doi. org/10.1007/s10493-012-9522-4.

Mans, B.J., Pienaar, R., Latif, A.A., 2015. A review of Theileria diagnostics and epidemiology. Int. J. Parasitol. 4, 104-118. https://doi.org/10.1016/j. ijppaw.2014.12.006. Including Articles from 'International Congress on Parasites of Wildlife', pp. 49 - 158.

Mohamed, G., Ebied, M.H., 2014. Epidemiological studies on bovine Babesiosis and Theileriosis in Qalubia governorate. BVMJ 27, 36-48.

Nijhof, A.M., Penzhorn, B.L., Lynen, G., Mollel, J.O., Morkel, P., Bekker, C.P.J., Jongejan, F., 2003. Babesia bicornis sp. nov. and Theileria bicornis sp. nov.: tickBorne parasites associated with mortality in the black rhinoceros (Diceros bicornis). J. Clin. Microbiol. 41, 2249-2254. https://doi.org/10.1128/JCM.41.5.22492254.2003.

Nijhof, A.M., Pillay, V., Steyl, J., Prozesky, L., Stoltsz, W.H., Lawrence, J.A., Penzhorn, B. L., Jongejan, F., 2005. Molecular characterization of Theileria species associated with mortality in four species of African antelopes. J. Clin. Microbiol 43, 5907-5911. https://doi.org/10.1128/JCM.43.12.5907-5911.2005.

Nugteren, H., Le Côme, C., 2016. Libérer Le Potentiel Du Pastoralisme Pour Développer L'afrique De l'Ouest, Fred Zaal. Thea Hilhorst et Jacqueline Sluijs.

Radostits, O.M., Gay, C.C., Hinchcliff, K.W., Constable, P.D., 2006. Veterinary Medicine E-Book: A textbook of the Diseases of Cattle, Horses, Sheep, Pigs and Goats. Elsevier Health Sciences.

Roy, B.C., Estrada-Peña, A., Krücken, J., Rehman, A., Nijhof, A.M., 2018. Morphological and phylogenetic analyses of Rhipicephalus microplus ticks from Bangladesh, Pakistan and Myanmar. Ticks Tick-Borne Dis. 9, 1069-1079. https://doi.org/ 10.1016/j.ttbdis.2018.03.035.

Schouls, L.M., Pol, I.V.D., Rijpkema, S.G.T., Schot, C.S., 1999. Detection and identification of ehrlichia, borrelia burgdorferi sensu lato, and bartonella species in Dutch ixodes ricinus ticks. J. Clin. Microbiol. 37, 2215-2222. https://doi.org/ 10.1128/JCM.37.7.2215-2222.1999. 
Silatsa, B.A., Simo, G., Githaka, N., Mwaura, S., Kamga, R.M., Oumarou, F., Keambou, C., Bishop, R.P., Djikeng, A., Kuiate, J.-.R., Njiokou, F., Pelle, R., 2019. A comprehensive survey of the prevalence and spatial distribution of ticks infesting cattle in different agro-ecological zones of Cameroon. Parasites Vectors 12, 489. https://doi.org/ 10.1186/s13071-019-3738-7.

Simuunza, M., Weir, W., Courcier, E., Tait, A., Shiels, B., 2011. Epidemiological analysis of tick-borne diseases in Zambia. Vet. Parasitol. 175, 331-342. https://doi.org/ 10.1016/j.vetpar.2010.09.027.

Sisson, D., Hufschmid, J., Jolles, A., Beechler, B., Jabbar, A., 2017. Molecular characterisation of Anaplasma species from African buffalo (Syncerus caffer) in Kruger National Park, South Africa. Ticks Tick Borne Dis 8, 400-406. https://doi. org $/ 10.1016 / j$.ttbdis.2017.01.003.

Stachurski, F., Musonge, E.N., Achu-kwi, M.D., Saliki, J.T., 1993. Impact of natural infestation of Amblyomma variegatum on the liveweight gain of male Gudali cattle in Adamawa (Cameroon). Vet. Parasitol. 49, 299-311. https://doi.org/10.1016/ 0304-4017(93)90128-A.
Vrijenhoek, R., 1994. DNA primers for amplification of mitochondrial cytochrome c oxidase subunit I from diverse metazoan invertebrates. Mol. Mar. Biol. Biotechnol. 3, 294-299.

Walker, A., A. Bouattour, J.-.L. Camicas, A. Estrada-Peña, I.G. Horak, A.A. Latif, R.G. Pegram, P.M. Preston, 2003. Ticks of domestic animals in Africa: a guide to identification of species. Bioscience Reports, Edinburgh.

Yisaschar-Mekuzas, Y., Jaffe, C.L., Pastor, J., Cardoso, L., Baneth, G., 2013. Identification of Babesia species infecting dogs using reverse line blot hybridization for six canine piroplasms, and evaluation of co-infection by other vector-borne pathogens. Vet. Parasitol. 191, 367-373. https://doi.org/10.1016/j.vetpar.2012.09.002.

Zannou, O.M., Ouedraogo, A.S., Biguezoton, A.S., Lempereur, L., Patrick Yao, K., Abatih, E., Zoungrana, S., Lenaert, M., Toe, P., Farougou, S., Saegerman, C., 2020. First digital characterization of the transhumance corridors through Benin used by cattle herds from Burkina Faso and associated risk scoring regarding the invasion of Rhipicephalus (Boophilus) microplus. Transbound. Emerg. Dis. https://doi.org/ 10.1111/tbed.13855. 